\title{
CDS Primi ve Faiz Oranının BİST Banka Endeksine Etkisi: Türkiye Üzerine Ampirik Bir İnceleme (Araştırma Makalesi)
}

The Impact of CDS Premium and Interest Rate on BIST Bank Index: An Empirical Analysis on Turkey

Doi: 10.29023/alanyaakademik.749032

\section{Bakhtiyar GAREYEV}

Yüksek Lisans ögrencisi, Anadolu Üniversitesi, Sosyal Bilimler Enstitüsü

ORCID No: 0000-0002-5789-6368

bakhtiyar.garayev@gmail.com

\section{Merve ÇELIKK KEĊILİ}

Arş. Grv., Anadolu Üniversitesi, Açık Öğretim Fakültesi, İktisadi ve İdari Programlar Bölümü

ORCID: 0000-0003-0105-1363

mervecelik722@anadolu.edu.tr

\section{Ethem ESEN}

Doç. Dr., Anadolu Üniversitesi, İ̈BF, İktisat bölümü

ORCID: 0000-0002-5356-1798

etheme@anadolu.edu.tr

\section{Fatih TEMIZEL}

Prof. Dr., Anadolu Üniversitesi, İ̈BF, İktisat bölümü

ORCID: 0000-0002-7208-3293

ftemizel@anadolu.edu.tr

How to cite this article: Gareyev, B., Çelik Keçili, M., Esen, E. \& Temizel F. (2021). "CDS Primi ve Faiz Oranının BIST Banka Endeksine Etkisi: Türkiye Üzerine Ampirik Bir İnceleme”, Alanya Akademik Bakış, 5(1), Sayfa No 231-244.

Anahtar kelimeler:
BIST Banka Endeksi,
Faiz Orani, CDS
Makale Geliş Tarihi:
O7.06.2020
Kabul Tarihi:
24.11.2020

\section{ÖZET}

Bu çalışmada, makroekonomik değişkenlerden CDS Primi ve faiz oranlarının Türkiye'deki bankaların karlıllğına olan etkileri incelenmiştir. Analiz için BIST Banka endeksi, TCMB faiz oranları ve kredi temerrüt swapı (CDS) primleri ele alınmıs, 2015-2019 yıllarını kapsayan aylık veriler ve bu verilerin yüzdesel değişimleri kullanılmıştır. İncelenen değişkenler arasında ilişkinin mevcut olup olmadĭ̆ , ilişki varsa ne yönde olduğu araştırılmıştır. Illişkinin belirlenmesi ve etkisinin tahmin edilmesi için VAR modeli uygulanarak Granger nedensellik testi, etki-tepki analizi ve varyans ayrıştırması analizi kullanılmıştır. Uygulanan analizler sonucunda, BISST banka endeksi ile faiz oranı ve CDS primleri arasında tek yönlü bir nedensellik ilişkisinin olduğu tespit edilmiştir. 
Keywords:

BIST Bank Index, Interest Rate, $C D S$

\begin{abstract}
In this study, the CDS premium and interest rates from the macroeconomic variables were examined impact the profitability of banks in Turkey.

For the analysis, BIST Bank index, the Central Bank of Turkey interest rates and credit default swap (CDS) premiums were taken into consideration, monthly data covering the years 2015-2019 and the percentage changes of these datas were used. It was investigated whether there was a relationship between the variables examined, and if there was a relationship, in what direction. Granger causality test, Impulse-Response, and Variance decomposition analysis were used by applying VAR model to determine the relationships and estimate its effects. As a result of the analysis, it has been determined that there is a one-way causality relationship between the BIST bank index and the interest rate and CDS premiums.
\end{abstract}

\section{GİRIŞ}

Ticaretin gelişmesi bankacılık sektörünün de gelişmesinde önemli bir etken olurken, bu gelişme bankaların ekonomik sistem içerisindeki önemini ve sayısını artırmıştır. Özellikle son yıllarda yaşanan ekonomik küreselleşme ile birlikte ülkelerin ticari bakımdan sınırları aşması ve yoğun teknolojik gelişmeler etkisini finans alanında da göstermiş, finansal pazarların bütünleşmesiyle ekonomik sistem içerisinde bankacılık sektörünün işlevi daha da artmıştır.

Finansal aracılık işlevini yerine getiren bankalar, kaynak büyüklüğü ile finansal sektörün de temelini oluşturmaktadır. Sektörün hızla gelişmesiyle nakit akışları, bilanço büyüklükleri ve net kârlarda meydana gelen artış, bankaların borsada işlem gören hisse senetlerine olan ilgiyi artırarak banka getirilerini de önemli şekilde etkilemiştir. Bu etki hisse fiyatlarına da yansımaktadır. Bankaların hisse senetlerinin borsada işlem görmesiyle birlikte sektörün getirileri sadece banka sahiplerini ve ortaklarını değil, aynı zamanda yatırımcıları da ilgilendirmektedir.

Teknolojinin gelişimiyle beraber, sektörde yerli ve yabancı bankalar arasındaki rekabet yarışı da artmaktadır. Bu durum bankaları yeni ürünler ortaya koymaya ve bu ürünleri pazarlamaya, faaliyetlerini geliştirmeye, maliyetlerini düşürmeye yönelik önlemler almaya itmiştir (Yıldırım, 2014: 54). Bu süreçte bankacılık sektörünün getirileri çeşitlenmiş ve kârları da artmıştır. Bankaların portföyleri gelişirken, portföy getirilerini etkileyen faktörler de artmaktadır.

Sektörün karlılıkları ve portföy performansları birçok faktörden etkilenebilmektedir. Makroekonomik değişkenler ise bu faktörlerden biridir. Literatür çalışmaları değerlendirildiğinde sektörde önemle takip edilen makroekonomik değişkenlere faiz oranı, CDS (kredi temerrüt takası) döviz kuru, enflasyon vb. örnek verilebilir. Bu araştırmada, Türkiye'nin bankacılık sektörüne etkisi olabilecek makroekonomik değişkenlerden faiz oranı ve CDS (kredi temerrüt takasi) primi üzerinde durulmuştur.

Literatürde sıklıkla makroekonomik değişkenlerin hem bankacılık hem de genel olarak piyasadaki hisse senetlerine etkisi ele alınmıştır (Hashemzadeh ve Taylor, 1988; Kwon ve Shin,1999;Özbay, 2009). Ancak bankacılık sektörünün kârlılığını etkileyen makroekonomik faktörlerle ilgili araştırma sayısı oldukça kısıtlıdır. Çalışmada bankacılık sektörü getirilerini 
BİST Banka getiri endeksi temsil etmektedir. Bununla birlikte endeks getirisinin baz alınması çalışmanın özgün değerini artırmaktadır.

\section{LITTERATÜR}

Literatürde makroekonomik değişkenlerin piyasada işlem gören hisse senetlerine olan etkisine dair araştırmalara sıkça rastlanmaktadır. Bu değişkenlerin bankacılık sektörünün kârlılığı üzerindeki etkisi az sayıdaki çalışmada yer almıştır. Bu nedenle literatür taramasında makroekonomik değişkenlerin hem bankacılık sektörü, hem de genel olarak piyasada işlem gören hisse senetleri ve diğer makroekonomik değişkenler üzerindeki etkisinden bahseden çalışmalar ele alınmıştır.

Faiz, paranın kullanım hakkından gelecekte daha fazla getiri elde edebilmek amacıyla vazgeçmeyi ifade etmektedir. Ekonomilerde fon fazlası olan kesim, diğer bir ifadeyle giderleri gelirlerinden daha az olan bireyler (Surplus Spending Unit) tasarruf yaparak yatırım yapmak isteyenlere bu fazlayı arz eder. Diğer yandan da fon ihtiyacı olanlar (Deficit Spending Units) yeterli sermayenin olmadığ 1 durumlarda bu fazlayı talep ederek karşılığında belirli miktarda faiz öder. $\mathrm{Bu}$ nedenle faiz, farklı açılardan kâr veya maliyet olarak değerlendirilebilir. Faiz oranlarındaki her bir artış hisse senetlerinde azalışa veya bu oranlardaki azalış hisse senetlerinde artışa neden olmaktadır (Geske, 1983: 33). Farklı çalışmalarda faiz oranlarındaki artışın hisse senetlerinin fiyatlarında azalmaya neden olacağına yönelik gözlemlere rastlanmıştır (Hashemzadeh ve Taylor, 1988: 1603-1611). Güney Doğu Asya ülkelerinde yapılan çalışmalarda faiz oranıyla hisse senetleri fiyatları arasında nedensellik ilişkileri tespit edilmiştir. Tayland, Singapur ve Filipinler'de faiz oranı ve genel piyasadaki hisse senetleri arasında negatif, Endonezya ve Malezya'da ise pozitif bir ilişki belirlenmiştir (Wobangpo ve Sharma, 2002: 27-51). Başka bir çalışmada İngiltere Merkez Bankası tarafından belirlenen faiz oranlarının hisse senetleri üzerinde etkisi olduğu tespit edilmiştir (Gregoriou vd., 2009: 401-410). Purnandam (2007) ise çalışmasında, finansal sıkıntı olasılığı yüksek olan ABD bankalarının faiz oranı riskini karşılamak için daha yoğun türev kullandığını ve türev kullanmayan bankaların daha tutucu bilanço politikaları izlediğini ifade etmiştir.

Türkiye'de faaliyet gösteren bankalar özelinde yapılan çalışmalarda da bu ilişkiye yönelik tespitler yapılmıştır. Demirgüç-Kunt ve Huizinga (1999), 1988-1995 döneminde net faiz geliri ile kârının (toplam varlıklara göre) banka seviyesi özellikleri ve makro değişkenlerle ilişkisini inceleyerek faiz oranlarının her iki kâr ölçümü üzerinde olumlu bir etkisi olduğunu tespit etmiştir. Yüksek gelire sahip ülkelerde ise bu etki zayıflatılmış veya geçersiz kılınmıştır. Diğer yandan Borsa İstanbul'da işlem gören gıda, tekstil, mobilya, metal, tütün, petrol ürünleri ile kimya ürünleri sektörlerindeki firmaların hisse senetleri ile faiz oranı arasında pozitif ilişsi belirlenmiştir (Türksoy vd., 2008: 49-57). Kaya ve Doğan (2005) çalışmalarında, makroekonomik yönden gelişmelere ve faizlerde mevcut olan gerilemeye bağlı olarak bankaların aracılık faaliyetini daha etkin yaptıklarını ortaya koymuşlardır.

Özbay (2009); faiz oranı, döviz kuru, para arzı ve enflasyonun Türkiye'de hisse senedi fiyatlarına olan etkisini Granger nedensellik testi ile incelemiştir. Çalışmanın sonuçları hisse senedi ile faiz oranı arasında negatif ilişki olduğunu ortaya koyarken, faiz oranı ve enflasyonun hisse senedi getirilerinin Granger nedeni olduğunu göstermektedir. Diğer yandan faiz oranı banka getirisinin önemli kısmını oluşturduğundan, faizde artış olduğu durumlarda banka hisselerinde olumsuz etki yaratacağı beklentilerine rağmen, incelenen bankaların 
yarısının hisselerinde artış gözlemlenmiştir. (Demir ve Göçmen-Yağcılar, 2009: 379-408). Sayılgan ve Süslü (2011) gelişmekte olan ülkelerde ve Türkiye'de faiz ile bankaların hisse senetleri arasında anlamlı bir sonucun olmadığını tespit etmişlerdir. Taşkın (2011) araştırmasında, bankaların getirisine etki eden faktörleri belirlemiş, banka getirisinin makroekonomik faktörle anlamlı ilişkisinin olmadığını tespit etmiştir. Ayrıca faizi etkileyen faktörlerden biri de risk algısıdır. $\mathrm{Bu}$ algının azalmasıyla tasarruflar azalır ve hisse senetlerinde yükselişe neden olabilir (Adanur ve Nargeleçekenler, 2012: 103-128).

CDS'ler; alıcının, referans şirket veya ülkenin kredi riskini, belirli bir periyodik prim karşılığında satıcıya devretmekte olduğu sözleşmelerdir (Kamışlı ve Esen, 2018). Örneğin, borç veren, bir borçlunun borcunun temerrüde düşeceğinden endişe duyuyorsa, borç veren bu riski dengelemek veya değiştirmek için CDS kullanabilir. Dolayısıyla, CDS'ler korunma amacı doğrultusunda geliştirilmiş sözleşmelerdir. Bu amaçla geliştirilen CDS'ler 2000'li yıllarla birlikte giderek daha çok rağbet görmeye başlamıştır (Kamışlı ve Esen, 2019). Uluslararası kapsamda olan yatırımcıların herhangi bir ülkeye doğrudan yatırım veya portföy yatırımları gibi yatırımlarında karar almalarında ülkelerin kredi riskini doğru değerlendirmeleri çok önemlidir. $\mathrm{Bu}$ riskin belirlenmesinde $\mathrm{CDS}$ primlerinden faydalanılmaktadır.

Merton'un (1974) varsayılan temerrüt modelleri, kredi riski fiyatlandırması için ekonomik olarak sezgisel bir çerçeve sunmaktadır ve bu modeller kurumsal kredi marjlarını analiz etmek için yaygın olarak kullanılmaktadır. Temerrüt varlıklarının değeri tahvilin vadesinde varsayılan sınırın altında olduğunda oluşmaktadır. Riskli bir tahvilin değeri, firmanın varlık ve kaldıraç getirisindeki varyansın yanı sıra risksiz faiz oranlarındaki varyasyon ile ilgilidir. Benkert (2004) bu teorinin CDS fiyatlandırması için de geçerli olduğunu göstermektedir.

Ming (1998) araştırmasında, gelişmekte olan ülke tahvilleri ve Amerika Hazine tahvillerinin getirilerindeki farkı araştırmıştır. Borç/ Gayrisafi Yurtiçi Hâsıla (GSYİH), iç-dış borç çevirme oranlarının istatistiksel olarak anlamlı olduğu belirlenmiştir. Ayrıca bu faktörlerin ülkenin borcunu geri ödeme becerisinde ön plana çıktığı belirtilmiştir.

Kârı yüksek işletmeler temerrüt durumuna yatırım yapılabilir işletmelere göre daha yakındır. $\mathrm{Bu}$ nedenle hisse senetleri ve CDS arasındaki bilginin kârlı işletmelerde daha fazla olması beklenmektedir (Fung vd., 2008). Coronado vd. (2011), CDS'ler ile hisse fiyatları arasında güçlü ve negatif bir korelasyon olduğunu ortaya koymuşlardır. Bununla birlikte CDS ve sermaye piyasalarının incelendiği ülkelerde Granger nedensellik ilişkisi olduğu belirlenmiştir. Başarır ve Keten (2016), aylık verilerle 2010 ile 2016 arası dönemde, JP Morgan EMBI endeksi içerisinde yer alan 12 gelişmekte olan ülkenin CDS primleriyle döviz kurları ve hisse senedi endeksleri arasındaki ilişkiyi incelemişlerdir. Johansen eşbütünleşme yönteminin ve Granger nedensellik testinin kullanıldığı çalışmanın sonucunda; CDS primleriyle hisse senetleri arasında çift yönlü nedensellik ilişkisi saptanmıştır.

CDS'ler, ülkenin finansal durumuna göre negatif veya pozitif bilgi vermektedir. Negatif bilgiler CDS primlerini artırmakta, pozitif bilgiler ise primleri azaltmaktadır. Piyasanın likiditesi artınca, bu hareketler daha iyi algılanabilir (Kliber, 2011:111-128). Pollege ve Posch (2013) çalışmalarında, 2000 ve 2010 yıllarını kapsayan dönemde on üç Avrupa ülkesini inceleyerek, CDS piyasasının risklere tahvil piyasasından daha hızlı tepki verdiğini tespit etmişlerdir. Koy (2014) sekiz Avrupa ülkesinin CDS ile Euro tahvil primleri arasındaki nedensellik ilişkisini incelemiştir. Çalışmada İtalya ve Fransa'ya ait CDS'lerin tahvil 
primlerine etkisi saptanmıştır. Kamışlı (2020) ise Türk bankacılık sektörü tarafından alınan toplam sendikasyon kredileri ile Türkiye 5 yıllık CDS primi ve farklı risk göstergeleri arasındaki ilişkiyi nedensellik testleri ile analiz etmiştir. Çalışmada uygulanan Granger nedensellik ve asimetrik nedensellik testleri sonucunda Türkiye 5 yıllık CDS primi ile sendikasyon kredileri arasında ilişki tespit edilmiş, CDS primlerinde yaşanan artışların sendikasyon kredilerinde azalışa neden olduğu ortaya konmuştur.

\section{YÖNTEM ve VERİ SETİ}

BİST Banka endeksi, borsada işlem gören bankaların hisselerini temsil etmektedir. Çalışmada, BİST Banka endeksi ile makroekonomik değişkenlerden faiz oranı ve CDS primi arasındaki ilişkinin belirlenmesi amaçlanmıştır. Bu amaç doğrultusunda iki analiz yöntemi kullanılmıştır. Çalışmanın varsayımları ele alınarak öncelikle BIST Banka endeks getirisi ile makroekonomik değişkenler arasındaki ilişki çoklu doğrusal regresyon modeli ile incelenmiş, ardından VAR modeli ile ilişkiler analiz edilmiştir.

BİST Banka $=b_{0}+b_{1}$ Faiz oran $1+b_{2}$ CDS oran $1+u$ (hata terimi)

Kurulan modelde $b_{1}$ ve $b_{2}$ bahsedilen değişkenlerin etkisini, $u$ ise hata terimini göstermektedir.

Çalışmada kullanılan veri seti oluştururken literatürde yer alan mevcut araştırmalardan faydalanılmıştır. Bağımlı değişken olarak BİST Banka Endeksi (BBANK), bağımsız değişkenler olarak ise, faiz oranı (FAIZ) ve CDS primleri (CDS) kullanılmıştır. CDS primlerinde 1 ve 10 yıla kıyasla, 5 yıllık aylık verileri kullanmak daha yaygın olduğundan 2015-2019 yıllarını kapsayan aylık veriler dikkate alınmıştır. Banka endeksi ve CDS primleri Thomson Reuters DataStream veri tabanından, faiz oranları ise TCMB'nin resmi sitesinden ${ }^{1}$ elde edilmiştir. Serilerin logaritmaları alınarak çalışma sürdürülmüştür. Çalışmada uygulanan analizlerde verilerin yüzdesel değişimi ele alınmıştır. Bunun nedeni tüm değişkenlerin ortak birimde incelenmesi gerekliliğidir.

Vector Autoregressive (VAR) modelleri, zaman serisi analizlerinde sıklıkla kullanılmaktadır. Model kurulurken tüm değişkenler içsel kabul edilir ve kısıtlamalara yer verilmez. Aynı zamanda ekonomik ve finansal değişkenler arasındaki dinamik analizler, VAR modelleri ile yapılabilir. $\mathrm{Bu}$ çalışmada da belirtilen değişkenler arasındaki ilişsiler, VAR modeli ile araştırılmıştır.

Sahte regresyon sorunu ile karşılaşmamak ve VAR analizinin ön koşulu olarak, modele dahil edilecek serilerin durağan olması gerekmektedir. Bu nedenle VAR analizi uygulamasından önce Genişletilmiş Dickey Fuller (ADF) birim kök testi uygulanmış ve serilerin durağanlığı analiz edilmiştir. Daha sonra VAR modelinin optimal gecikme uzunluğu, modelin stabilite koşullarına (otokorelasyom, değişen varyans ve normallik) bağlı olarak tespit edilmiştir.

Çalışmada, değişkenler arasındaki ilişkinin varlığı ve yönünü analiz etmek için Granger nedensellik testi kullanılmıştır. Etki-tepki fonksiyonları ise rassal şokun, içsel faktörlerin bugünkü ve gelecekte olabilecek değerlerine olan etkisini göstermektedir. Son olarak varyans ayrıştırması ile makroekonomik değişkenlerin BİST Banka endeksine ilgili dönem

\footnotetext{
${ }^{1}$ https://www.tcmb.gov.tr/
} 
içerisindeki etkisi araştırılmıştır. Söz konusu analizler, Eviews ${ }^{2} 10$ programı kullanılarak uygulanmıştır.

\section{ARAŞTIRMA BULGULARI}

Çalışmada öncelikle ele alınan değişkenlerin zaman içerisindeki değişimleri grafiksel olarak incelenmiştir. Şekil 1'de çalışmada kullanılan değişkenlerin zaman içerisinde aldıkları değerler görülmektedir. Buna göre serilerin durağan olmadığı, şoklardan dolayı dalgalanmaların meydana geldiği gözlemlenmektedir.
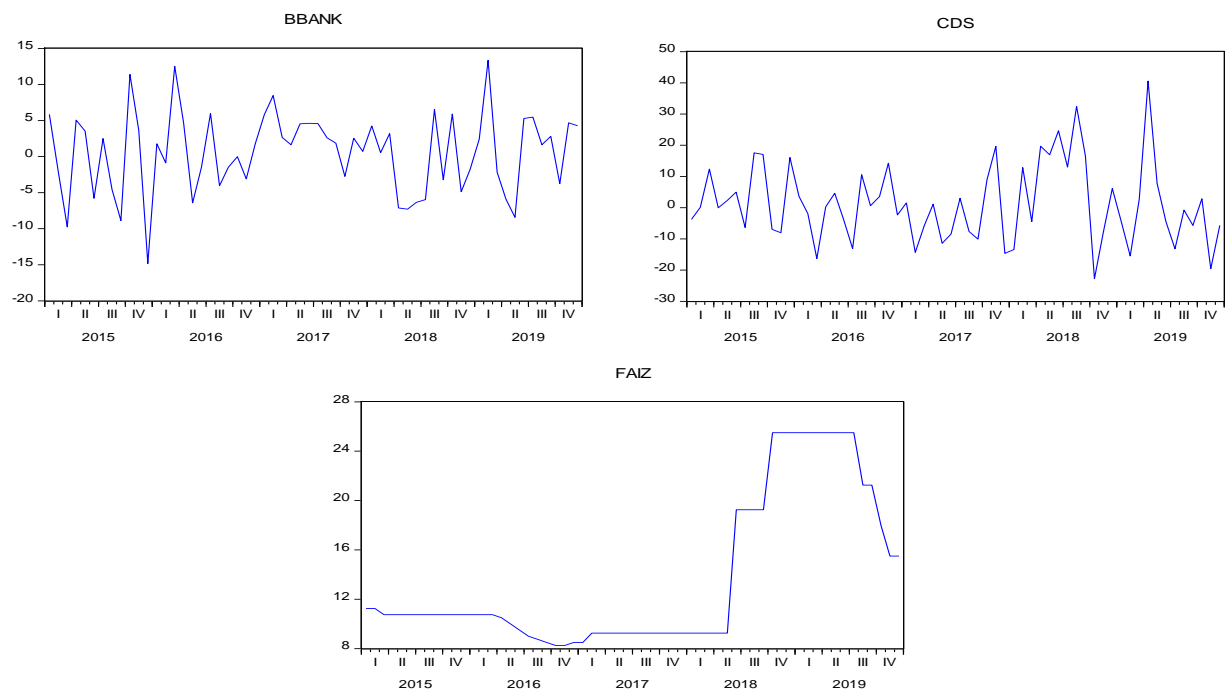

Şekil 1. Kullanılan Değişkenlerin Yüzdesel İfadesinin Grafiksel Hali

\subsection{Birim Kök Testi}

Durağan olmayan seriler ele alındığında sahte regresyon sorunuyla karşılaşılmaktadır. Bu nedenle çalışmada baz alınan değişkenlerin durağanlıkları Dickey ve Fuller (1981) tarafından geliştirilen Genişletilmiş Dickey Fuller (ADF) testi ile analiz edilmiştir. Gecikme uzunluğu olarak Schwarz Bilgi Kriteri (SIC), maksimum gecikme ise 10 olarak belirlenmiştir. Logaritmik dönüşümler yapıldıktan sonra veri setinin birim kök analizi yapılmıştır.

ADF birim kök testi hipotezi şu şekildedir:

$$
\begin{aligned}
& \mathrm{H}_{0}: \delta \geq 0 \text { Birim kök vardır ve seri durağan değildir. } \\
& \mathrm{H}_{1}: \delta<0 \text { Birim kök yoktur ve seri durağandır. }
\end{aligned}
$$

Tablo 1, durağanlık testinin sonuçlarını göstermektedir. BBANK ve CDS değişkenleri göz önünde bulundurulduğunda, düzeyde $\mathrm{H}_{0}$ hipotezi reddedilmekte ve seriler durağandır. FAIZ serisi için düzeyde $\mathrm{H}_{0}$ hipotezi reddedilmemekte ve seri birim kök içermektedir. Ancak FAIZ serisinin farklı alındığında seri durağan hale gelmektedir. Tablo 1'den görülebileceği gibi

(TCMB Faiz oranları (\%), 2020) 
serilerin aynı seviyede durağan olmadığı tespit edilmiştir. Bu nedenle ilerleyen aşamada VAR modeli kurularak kısa dönemli ilişkiler bu model vasıtasıyla incelenmiştir.

Tablo 1. ADF Birim Kök Testi

\begin{tabular}{|c|c|c|c|c|}
\hline \multirow{2}{*}{ Değişkenler } & \multicolumn{2}{|c|}{ Seviye } & \multicolumn{2}{c|}{ 1. Seviye } \\
\cline { 2 - 5 } & Sabit & Olas1lık Değeri & Sabit & Olasıllk Değeri \\
\hline BBANK & -7.026 & 0.0001 & -7.829 & 0.0001 \\
\hline CDS & -6.118 & 0.0001 & -7.719 & 0.0001 \\
\hline FAİZ & -1.066 & 0.723 & -7.122 & 0.0001 \\
\hline
\end{tabular}

\subsection{Otokorelasyon Testi}

Otokorelasyon testinde hipotezler şu şekildedir:

$\mathrm{H}_{0}$ : $\mathrm{x}$ gecikmesinde otokorelasyon yoktur.

$\mathrm{H}_{1}$ : x gecikmesinde otokorelasyon vardir.

Tablo 2'den görülebileceği gibi VAR modelinde 10 gecikme için otokorelasyon sorunu bulunmamaktadır.

Tablo 2.Otokorelasyon Testi

\begin{tabular}{|c|c|c|c|c|}
\hline Gecikme & LRE* stat & Olasıllk & Rao F-stat & Olasillk \\
\hline 1 & 14.639 & 0.1013 & 1.8160 & 0.1040 \\
\hline 2 & 12.174 & 0.2037 & 1.4551 & 0.2073 \\
\hline 3 & 9.0703 & 0.4308 & 1.0352 & 0.4347 \\
\hline 4 & 6.6372 & 0.6748 & 0.7309 & 0.6777 \\
\hline 5 & 7.1212 & 0.6245 & 0.7898 & 0.6277 \\
\hline 6 & 8.9698 & 0.4401 & 1.0222 & 0.4440 \\
\hline 7 & 3.9464 & 0.9149 & 0.4179 & 0.9158 \\
\hline 8 & 7.1160 & 0.6250 & 0.7891 & 0.6282 \\
\hline 9 & 7.4619 & 0.5891 & 0.8317 & 0.5925 \\
\hline 10 & 6.3600 & 0.7034 & 0.6975 & 0.7061 \\
\hline
\end{tabular}




\subsection{Normallik Testi}

Normallik testi hipotezleri;

$\mathrm{H}_{0}$ : Hatalar çoklu normal dağılmaktadır.

$\mathrm{H}_{1}$ : Hatalar çoklu normal dağılmamaktadır.

Tablo 3. Normallik Testi

\begin{tabular}{|c|c|}
\hline Ki-kare & Olasilık \\
\hline 5.929740 & 0.4311 \\
\hline
\end{tabular}

Tablo 3'te test sonuçları görülmektedir. Buna göre $\mathrm{H}_{1}$ hipotezi kabul edilmiş ve hata terimlerinin çoklu normal dağılım göstermediği belirlenmiştir.

\subsection{Değişen Varyans Testi}

VAR modelinde değişen varyansı test etmek için White Heteroscedasticity (no cross terms) testi uygulanmıştır. Testin boş hipotezi;

$\mathrm{H}_{0}$ : Değişken varyans yoktur.

Tablo 4. White Heteroscedasticity (no cross terms) Testi

\begin{tabular}{|c|c|}
\hline Ki-kare & Olasilık \\
\hline 223.3257 & 0.3512 \\
\hline
\end{tabular}

Tablo 4'ten görülebileceği gibi $\mathrm{H}_{0}$ hipotezi kabul edilmekte $(0.3512)$ ve modelde değişen varyans sorunu bulunmamaktadır.

\subsection{Granger Nedensellik Testi}

VAR modeli stabilite koşulları sağlandıktan sonra, değişkenler arasında ilişkinin yönünü tespit etmek üzere Granger nedensellik testi uygulanmıştır. Nedensellik testinde a değişkeni b değişkenin tahminine yardım ediyorsa a, b’nin nedenidir şeklinde bir ifadede bulunmak mümkündür (Granger, 1969). Bu testin boşluk hipotezi şu şekildedir:

$$
\mathrm{H}_{0} \text { : a, b'nin Granger nedeni değildir. }
$$

Nedensellik testi ile değişkenler arasındaki ilişkinin tek veya çift yönlü olduğu ya da olup olmadığı belirlenebilir. $\mathrm{H}_{0}$ hipotezinin kabulü durumunda a, b’nin Granger nedeni değil, aksi durumda ise nedenidir. 
Tablo 5.Granger Nedensellik Testi

\begin{tabular}{|l|l|}
\hline Sifir Hipotezi & Olasılık \\
\hline CDS BBANK' 'n Granger nedeni değildir. & 0.047 \\
FAIZ BBANK' 1 Granger nedeni değildir. & 0.003 \\
BBANK CDS'nin Granger nedeni değildir. & 0.472 \\
FAIZ CDS'nin Granger nedeni değildir. & 0.613 \\
BBANK FAIZ'in Granger nedeni değildir. & 0.336 \\
CDS FAIZ'in Granger nedeni değildir. & 0.812 \\
\hline
\end{tabular}

Tablo 5'ten görülebileceğe gibi sadece TCMB'nin uyguladı̆̆ı faiz oranlarından ve CDS primlerinden endeks getirisine tek yönlü nedensellik tespit edilmiştir. Bununla birlikte endeks getirisinden faiz oranlarına ve CDS primlerine ise nedensellik ilişkisi bulunmamaktadır.

\subsection{Etki Tepki Analizi}

Etki-tepki analizi, hata terimlerinden birinde meydana gelen şokun, bağımlı değişkenlerin bugün ve gelecek dönemde olan değerlere etkisini yansıtmaktadır. Bununla birlikte varyans ayrıştırması analiziyle etkisi en fazla olan değişken, etki tepki analiziyle ise etkili değişkenlerin kullanılabilirliği saptanmaktadır (Özgen ve Güloğlu, 2004: 97). Grafiksel olarak bu analiz değişkenlerin verdiği tepkileri ifade etmektedir.

Şekil 2'de etki-tepki analizi yardımıyla değişkenler arasında meydana gelen şoklar karşısında oluşan tepkiler gösterilmiştir. Monte Carlo tekniği ile hatalar türetilmiş, analizde nokta tahminini bulmak için 100'lük tekrarlanan güven sınırı kırmızı çizgilerle belirtilmiştir. Şekilde yer alan mavi çizgi nokta tahminlerini göstermektedir.

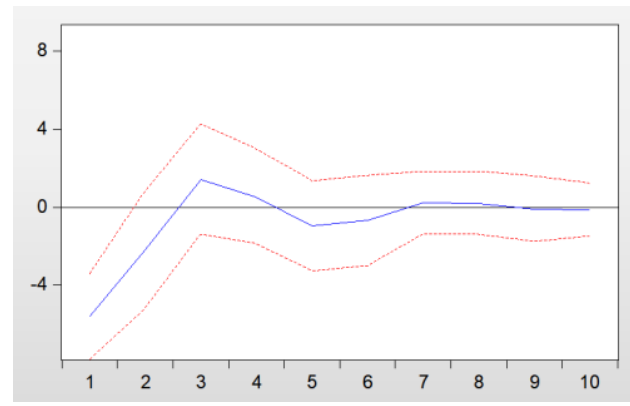

Şekil 2(a). BBANK'In CDS'ye Tepkisi

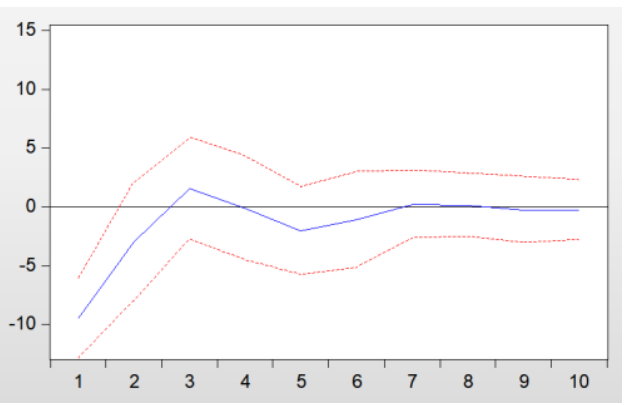

Şekil 2(b). CDS'nin BBANK'a Tepkisi

Şekil 2(a), CDS primlerindeki şokun BİST Banka hisse senedi fiyatlarına verdiği tepkiyi ifade etmektedir. Grafikten de görüldüğü gibi bu tepki yaklaşık 1 ay boyunca anlamlıdır ve negatiftir. Şekil 2(b)'de ise BBANK'ta meydana gelen şoka CDS'in verdiği tepki gösterilmektedir. Bu tepki de benzer şekilde yaklaşık 1 ay boyunca anlamlıdır ve negatiftir. 


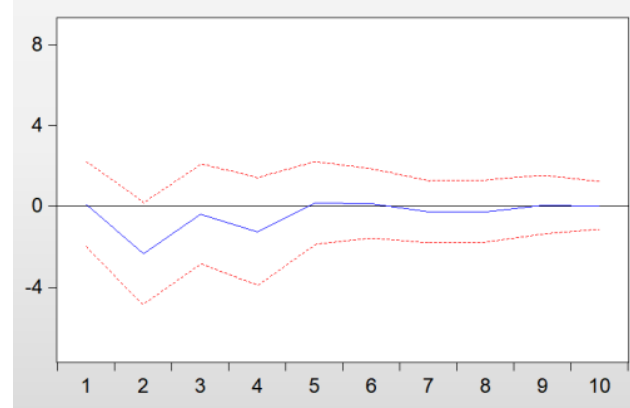

Şekil 3(c). BBANK'ın FAIZ'e Tepkisi

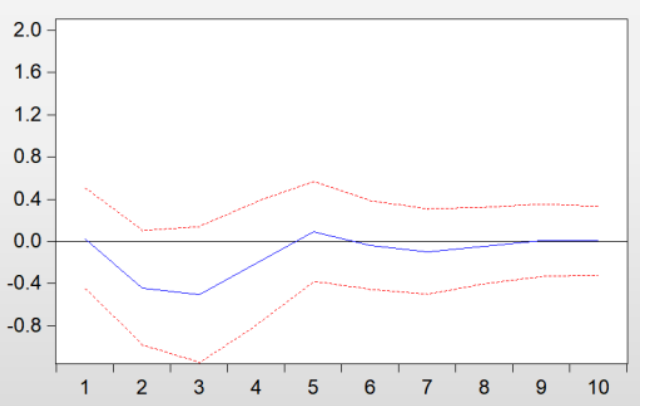

Şekil 3(d). FAIZ'in BBANK'a Tepkisi

Şekil 3(c), FAIZ değişkeninde yaşanan şokun BBANK üzerindeki etkisini, 3(d)'de ise BBANK değişkeninde yaşanan şokun FAIZ değişkeni üzerindeki etkisini göstermektedir. Her iki etki-tepki fonksiyonu da anlamlı değildir.

\subsection{Varyans Ayrıştırması}

Varyans ayrıştırması, bahsedilen değişkenlerde oluşan şok kaynaklarının yüzdesel ifadesidir. Meydana gelen değişimlerin yüzde kaçının kendisinden, yüzde kaçlık kısmının diğer değişkenlerden kaynaklandığını ifade etmektedir.

Tablo 6. Değișkenlerin Varyans Ayrıștırması

\begin{tabular}{|c|c|c|c|}
\hline Periyot & BBANK & FAİZ & CDS \\
\hline 1 & 100 & 0 & 0 \\
\hline 2 & 78.8240 & 16.7953 & 4.3806 \\
\hline 3 & 77.5795 & 17.8835 & 4.5370 \\
\hline 4 & 74.2591 & 17.0930 & 8.6479 \\
\hline 5 & 61.4444 & 26.5271 & 12.0285 \\
\hline 6 & 61.1944 & 26.4417 & 12.3639 \\
\hline 7 & 59.5474 & 27.2492 & 13.2034 \\
\hline 8 & 59.3861 & 26.4176 & 14.1963 \\
\hline 9 & 59.2441 & 26.5069 & 14.2490 \\
\hline 10 & 59.2970 & 26.5591 & 14.1440 \\
\hline
\end{tabular}

Tablo 6'da BBANK değişkeninde meydana gelen değişimler, kendisi ile birlikte faiz ve CDS değişkenleri ile birlikte gösterilmiştir. 10 dönemlik varyans ayrıştırmaları sonuçlarına göre BBANK'ta meydana gelen değişimler diğer makroekonomik değişkenlere göre kendinden 
kaynaklanmaktadır. Aynı zamanda ele alınan dönem boyunca BBANK değişkeninde meydana gelen değişimlerde faizin etkisi CDS'in olası etkisini geçmiş ve 10. dönemin sonunda $\% 26,55$ oranına yükselmiştir.

\section{SONUÇ}

Dünyada mevcut finansal gelişmeler sonucunda sermaye sahipleri, yatırımlarını farklı alanlarda değerlendirme olanağına kavuşmuştur. Son yıllarda bankaların faaliyetlerindeki gelişmeler yatırımcıların dikkatini çekmiş ve bankacılık sektöründeki getirilerin önemi artmıştır. Özellikle bankacılık sektöründeki hisse senetlerinin önem kazanması onu etkileyen faktörlerin araştırılmasını da önemli hale getirmiştir. Bununla birlikte hisse senetlerinin fiyatlarındaki dalgalanmalar, gelecekteki fiyatlarla ilgili tahmin yürütme konusunda yardımcı olabilmektedir. $\mathrm{Bu}$ nedenle hisse senetleri fiyatlarına etki edecek faktörlerin belirlenmesi yatırımcılar açısından oldukça önemlidir. Literatürde makroekonomik değişkenlerin borsa endeksine olan etkisini inceleyen çok sayıda çalışma bulunmaktadır. Ancak banka getirilerini baz alan araştırmalar oldukça sınırlıdır. Bu bağlamda BİST Banka hisse senetleri endeksi özelinde, farklı makroekonomik değişkenler ve kârlılık arasındaki ilişkinin araştırılması ile literatüre katkı sağlanacağı düşünülmektedir. Çalışmada BİST Banka hisse senedi endeksinin TCMB'nin uyguladığı faiz oranı ve Türkiye için CDS primleri ile olan ilişkisi araştırılmıştır. BİST Banka hisse senedi endeksinin getirisiyle makroekonomik değişkenler arasında tek yönlü anlamlı bir ilişki olduğu saptanmıştır.

Literatürde yer alan çalışmalarda genellikle faizde yaşanan değişimlerin banka kârlılığını etkilediği sonucuna ulaşılmıştır. Diğer bir ifadeyle faiz oranındaki azalış, banka kârlılığını artırmaktadır. Ancak bazı çalışmalarda söz konusu ilişki bulunsa da, bazı çalışmalarda anlamlı ilişki bulunamamıştır. Örneğin, Demir ve Göçmen (2009) tarafindan yapılan çalışmada faiz oranının arttığı dönemde araştırılmaya tabi tutulan bankaların yarısında kârlılık artmış; diğer yandan Sayılgan ve Süslü (2011) çalışmasında gelişmekte olan ülkelerdeki hisse senedi getirileri ile faiz oranı arasında istatistiksel olarak anlamlı bir ilişki tespit edilmemiştir. Bıtırak (2010) ise faiz oranının yatırım aracı olduğunu, hisse senetleri fiyatlarıyla da ters ilişkili olduğu sonucuna varmıştır.

Çalışmada VAR analizi ve ilişkilerin yönünün tespiti için kullanılan Granger nedensellik testi sonucunda faiz oranı ve banka endeksi arasında tek yönlü ilişki belirlenmiştir. Varyans ayrıştırması testine göre 10. dönemde BİST Banka endeksinde meydana gelen değişimlerin \%26,55'i faizden kaynaklanmaktadır. Bu sonuç, bankalara verilen borçlarda faiz oranlarının yükselmesi durumunda, bankaların hisse senedi getirisine pozitif yönde etki ettiği şeklinde yorumlanabilir. Ayrıca bankalar borçlarını daha yüksek faizle ödemeleri durumunda mevduata/borç verme oranları da yüksek olacaktır. Böylece kârlılıklarını yükseltebilecekleri düşünülebilir.

Çalışmada CDS primleri ile BBANK endeksi arasında da tek yönlü bir nedensellik ilişkisi tespit edilmiştir. Literatüre dikkat edildiğinde, ülkenin CDS puanının yüksek olması durumunda hisse senetlerinin riskli olduğu, hisse senetlerinin getirisi ile CDS primi arasında negatif bir ilişkinin varlığı gözlemlenmektedir. Coronado (2011) bu ilişkiyi Granger nedensellik analiziyle tespit etmiştir. CDS primlerinin yüksek olması halinde yatırımcılar risk almak istemeyebilirler. Bu durumda faizlerde artış olur. Granger nedensellik testi sonuçları bu ilişkiyi doğrulamaktadır. 
Çalışmanın banka yöneticileri, yatırımcılar ve araştırmacılar için önemli olabileceği kanaatine varılabilir. Portföylerini bankaların hisse senetleri ile genişletmek isteyen yatırımcıların TCMB'nin bankalara verdiği borçların faizlerindeki dalgalanmalara uygun tahmin yürütebilecekleri düşünülebilir. Ayrıca bankalardaki kârlılığın faizden doğan doğrusal kabul edilmeyen sonuçları, farklı analiz yöntemleriyle araştırılmalıdır. Bununla birlikte banka yöneticileri, faiz riskini dikkate aldıklarında bankanın piyasa değerini artırarak performanslarını pozitif etkileyebilirler. Yöneticilerin dışında söz konu ilişkinin belirlenebilmesi, özellikle gelişmekte olan ülkelerin banka kârlılığını araştıran yatırımcılar için de oldukça önemlidir.

\section{KAYNAKÇA}

ADANUR AKLAN, N. \& NARGELEÇEKENLER, M. (2012). "Hisse Senedi Piyasasında Para Politikalarının Rolü; Türkiye Örneği”. Marmara Üniversitesi İ.İ.B.F. Dergisi, 33(2): 103-128.

BAŞARIR, Ç. \& KETEN, M . (2016). "Gelişmekte Olan Ülkelerin CDS Primleri ile Hisse Senetleri ve Döviz Kurları Arasındaki Kointegrasyon İlişkisi”. Mehmet Akif Ersoy Üniversitesi Sosyal Bilimler Enstitüsü Dergisi, 8(15): 369-380.

BENKERT, C. (2004). "Explaining Credit Default Swap Premia". Journal of Futures Markets, 24: 71-92.

CORONADO, M., CORZO, T. \& LAZCANO, L. (2011). "A Case for Europe: the Relationshio between Sovereign CDS and Stock Indexes". Frontiers in Finance and Economics, 9(2): 32-63

DEMİG̈Ç-KUNT, A. \& HUIZINGA H. (1999). "Determinants of Commercial Bank Interest Margins and Profitability: Some International Evidence”. The World Bank Economic Review, 13 (2): 379-408.

DEMİR, Y. \& GÖÇMEN YAĞCILAR, G. (2009). “IMKB'de İşlem Gören Banka Hisse Senetlerinin Getirilerini Etkileyen Faktörlerin Arbitraj Fiyatlama Modeli ile Belirlenmesi”. Alanya İşletme Fakültesi Dergisi, 1/2: 36-51.

DICKEY, D. A. \& FULLER W. A. (1981). "Likelihood Ratio Statistics for Autoregressive Time Series with a Unit Root”. Econometrica, 49(4): 1057-1072.

FUNG, H. G., SIERRA, G. E., YAU, J., \& ZHANG, G. (2008). “Are the US Stock Market and Credit Default Swap Market Related?: Evidence from the CDX Indices”. The Journal of Alternative Investments, 11(1): 43-61.

GESKE, R. \& ROLL, R. (1983). “The Fiscal and Monetary Linkage between Stock Returns and Inflation". The Journal of Finance, 38(1): 32-33.

GRANGER, C. (1969). "Investigating Casual Relations by Econometric Models and CrossSpectral Methods". Econometrica, 37(3): 424-438.

GREGORIOU, A., KONTONIKAS, A., MACDONALD, R. \& MONTAGNOLI, A. (2009) (2009). "Monetary Policy Shocks and Stock Returns: Evidence From the British Market”. Financial Markets and Portfolio Management, 23(4): 401-410. 
HASHEMZADEH, N. \& TAYLOR, P. (1988). "Stock Prices, Money Supply, and Interest Rates: The Question of Causality”. Applied Economics, 20(12): 1603-1611.

KAMIŞLI, M. (2020). "Risk Göstergelerinin Sendikasyon Kredilerine Etkileri: Asimetri ve Frekans Boyutunda Analiz". Business \& Management Studies: An International Journal, 8(1): 181-195.

KAMIŞLI, S. \& ESEN, E. (2018). “Avrupa Ülkeleri CDS Endeksleri Arasındaki Oynaklık Yayılımlarının Analizi”. IMASCON 2018 Uluslararası Marmara Fen ve Sosyal Bilimler Kongresi, 23-25 Kasım, Kocaeli, Türkiye.

KAMIŞLI, S. \& ESEN, E. (2019). "Kredi Temerrüt Swapları Arasında Finansal Bağlantılılık”. BİLTÜRK Ekonomi ve İlişkili Çalışmalar Dergisi, 1(3), 258-270.

KAYA, Y. T. \& DOĞAN, E. (2005). "Dezenflasyon Sürecinde Türk Bankacılık Sektöründe Etkinliğin Gelişimi”. ARD Çalışma Raporları, BDDK Yayınları, (10): 1-16.

KLIBER, A. (2011). "Sovereign CDS Instruments in Central Europe-Linkages and Interdependence". Dynamic Econometric Models, (11): 111-128.

KOY, A.(2014). "Kredi Temerrüt Swapları ve Tahvil Primleri Üzerine Ampirik Bir Çalışma”. International Review of Economics And Management. 2(2): 63-79.

KWON, C. S., \& SHIN, T. S. (1999). Cointegration and causality between macroeconomic variables and stock market returns. Global finance journal, 10(1), 71-81.

MERTON, R. C. (1974). "On the Pricing of Corporate Debt: The Risk Structure of Interest Rates”. Journal of Finance, 29(2): 449-470.

MING, H.G. (1998). The Determinants of Emerging Market Bond Spread: Do Economic Fundamentals Matter. The World Bank Policy Research Working Paper 1899.

ÖZBAY, E. (2009). The Relationship Between Stock Returns and Macroeconomic Factors: Evidence for Turkey, University of Exeter Financial Analysis and Fund Management, Master Thesis.

ÖZGEN, F. B. \& GÜLOĞLU, B. (2004). "Türkiye'de İç Borçların İktisadi Etkilerinin VAR Tekniği ile Analizi”. METU Studies in Development, 3: 93-114.

POLLEGE, S. \& POSCH, P. N. (2013). "Managing and Trading Sovereign Risk Using Credit Derivatives and Government Markets". The Journal of Risk Finance, 14(5): 453-467.

PURNANDAM, A. (2007). "Interest Rate Derivatives at Commercial Banks: An Empirical Investigation". Journal of Monetary Economics, 54: 1769-1808.

SAYILGAN, G. \& SÜSLÜ, C., (2011). "Makroekonomik Faktörlerin Hisse Senedi Getirilerine Etkisi: Türkiye ve Gelişmekte Olan Piyasalar Üzerine Bir İnceleme”. BDDK Bankacılık ve Finansal Piyasalar, 5(1): 73-96.

TAŞKIN, F. D. (2011). “Türkiye'de Ticari Bankaların Performansını Etkileyen Faktörler”. Ege Akademik Bakış, 11(2): 289-298.

TCMB, Türkiye Cumhuriyeti Merkez Bankası, Gecelik Faiz oranları (\%) https://www.tcmb.gov.tr/,12.04.2020 
TÜRKSOY, T., GUNSEL, N. \& RJOUB, H. (2008). "Macroeconomic Factors, the APT and the Istanbul Stock Market". International Research Journal of Finance and Economics, 22: 49-57.

WOBANGPO, P. \& SHARMA, S. C. (2002). "Stock Market and Macroeconomic Fundamental Dynamic Interactions: ASEAN-5 Countries". Journal of Asian Economics, 13(1): 27-51.

YILDIRIM, O. (2014). Türk Bankacılık Sistemi, Seçkin Yayınevi, Ankara. 54. 